\title{
Too many nodules: Can we do better than computed tomography screening for lung cancer?
}

\author{
Victor van Berkel, MD, $\mathrm{PhD}$
}

\author{
From the Department of Cardiothoracic Surgery, University of Louisville, Louisville, Ky. \\ Disclosures: Author has nothing to disclose with regard to commercial support. \\ Received for publication Oct 11, 2015; accepted for publication Oct 18, 2015; available ahead of print Nov 21, \\ 2015. \\ Address for reprints: Victor van Berkel, MD, PhD, Department of Cardiothoracic Surgery, University of Louis- \\ ville, 201 Abraham Flexner Way, Ste 1200, Louisville, KY 40202 (E-mail: victor.vanberkel@louisville.edu). \\ J Thorac Cardiovasc Surg 2016;151:859-60 \\ $0022-5223 / \$ 36.00$ \\ Copyright (C) 2016 by The American Association for Thoracic Surgery \\ http://dx.doi.org/10.1016/j.jtcvs.2015.10.047
}

The National Lung Screening Trial, the results of which were published more than 4 years ago, ${ }^{1}$ brought hope to medical professionals who provide care for patients with lung cancer. For the first time, radiologic screening in the form of lowdose computed tomography (CT) scans were demonstrated to have a significant influence on survival, ${ }^{1}$ and there was anticipation that increasing the scope of CT screening would lead to earlier diagnosis of lung cancer and a national decrease in overall lung cancer mortality.

There was also some concern. During the first year of the screening study 26,309 patients were screened, nearly one-third of whom (7191 patients) had an abnormal pulmonary finding-yet only 270 of these patients were eventually determined to have lung cancer. This is a false positive rate of $96 \%$ for CT screening and unnecessary additional studies ranging from additional CT scans to percutaneous biopsy, bronchoscopy, or thoracoscopic exploration were done for a significant percentage of individuals. ${ }^{1}$ The cost of these additional procedures, both financially and physiologically, has been the major point of dissent for the widespread adoption of CT screening, ${ }^{2}$ although there is evidence that even with these limitations, CT screening remains cost-effective. ${ }^{3}$

Because of the lack of specificity with radiologic imaging, increased emphasis has been placed on finding biologic markers that could help differentiate malignant nodules from benign nodules within the lung parenchyma. There are 3 separate modalities that have shown particular promise, each of which takes a slightly different approach to the problem of identifying occult cancer.

The first is identification of bloodborne microRNAs. MicroRNAs are small, nonprotein-coding RNA strands that alter protein production. ${ }^{4}$ Although they were originally identified as intracellular mechanisms of protein control, they have subsequently been demonstrated to be secreted by certain cells ${ }^{5}$ and remain stable within the bloodstream. Several groups have identified distinct profiles of microRNAs in the blood of patients with early stage lung cancer that could potentially serve as an indirect blood test

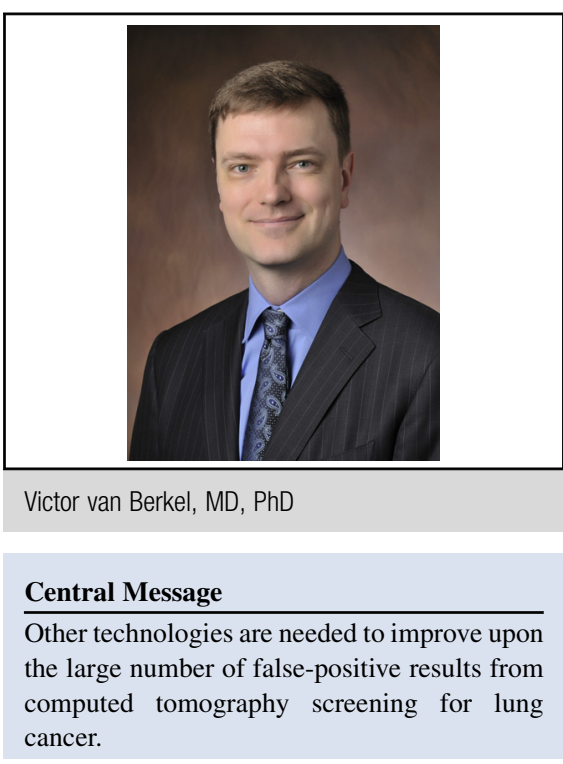

See Article page 852.

for lung cancer. ${ }^{6,7}$ These studies were in relatively small groups of patients, however, and identifying a reliable standardization method has proved challenging.

The second is the evaluation of exhaled breath. It has long been recognized that animals can identify a variety of ailments, including cancer, based on breath odors. ${ }^{9}$ Exhaled breath contains numerous volatile compounds that are the byproducts of metabolic processes; the capture and analysis of these compounds via numerous methods have identified several chemical profiles that are indicative of the presence of malignancy. ${ }^{10}$ Similar to microRNA testing, the specificity of these tests in larger populations still remains to be seen, although recent studies are encouraging. ${ }^{1 "}$

Finally there is the identification of circulating tumor cells. This represents a theoretical ideal of tumor screening, because the ability to identify circulating tumor cells would serve not only as a very specific marker of malignancy, but also provide genetic information that could identify the type of cancer, and conceivably lead to personalized chemotherapeutic treatments. Magnetic bead-based antibody separation of circulating tumor cells has been limited by a very low yield from peripheral blood, both in terms of the number of cells identified and the number of patients with known malignancies who had circulating tumor cells identified. $^{12}$ The low yield of cells from peripheral blood with these techniques limits the utility from a screening 
perspective and also makes improving the technique challenging because there are few identified cells to study.

An article in this issue by Reddy and colleagues ${ }^{13}$ successfully improves upon this yield by using an established microfluidic $\operatorname{chip}^{14}$ in addition to directly sampling blood from the pulmonary vein at the time of resection. Although sampling of pulmonary venous blood cannot be considered a tenable mechanism of screening patients, the substantial increase in identified cells provides a platform upon which further work can be based.

Although CT screening of at-risk populations holds great promise for decreasing the dismal long-term outcomes for patients with lung cancer, it is an incomplete solution to the problem. One of the developing technologies described above-or potentially some combination of all of them-may demonstrate the sensitivity and specificity to both decrease costs to the health care system and reduce unnecessary procedures.

\section{References}

1. National Lung Screening Trial Research Team, Aberle DR, Adams AM, Berg CD, Black WC, Clapp JD, et al. Reduced lung-cancer mortality with low-dose computed tomographic screening. N Engl J Med. 2011;365: 395-409.

2. Bach PB, Mirkin JN, Oliver TK, Azzoli CG, Berry DA, Brawley OW, et al. Benefits and harms of CT screening for lung cancer: a systematic review. JAMA. 2012;307:2418-29.
3. Goffin JR, Flanagan WM, Miller AB, Fitzgerald NR, Memon S, Wolfson MC, et al. Cost-effectiveness of lung cancer screening in Canada. JAMA Oncol, 2015;1:807-13.

4. Billeter AT, Druen D, Kanaan ZM, Polk HC Jr. MicroRNAs: new helpers for surgeons? Surgery. 2012;151:1-5.

5. Chen X, Liang H, Zhang J, Zen K, Zhang CY. Horizontal transfer of microRNAs: molecular mechanisms and clinical applications. Protein Cell. 2012;3:28-37.

6. Hennessey PT, Sanford T, Choudhary A, Mydlarz WW, Brown D, Adai AT, et al. Serum microRNA biomarkers for detection of non-small cell lung cancer. PLoS One. 2012; 7:e32307.

7. Boeri M, Verri C, Conte D, Roz L, Modena P, Facchinetti F, et al. MicroRNA signatures in tissues and plasma predict development and prognosis of computed tomography detected lung cancer. Proc Natl Acad Sci U S A. 2011;108:3713-8.

8. Billeter AT, Barnett RE, Druen D, Polk HC Jr, van Berkel VH. MicroRNA as a new factor in lung and esophageal cancer. Semin Thorac Cardiovasc Surg. 2012; 24:155-65.

9. McCulloch M, Jezierski T, Broffman M, Hubbard A, Turner K, Janecki T. Diagnostic accuracy of canine scent detection in early- and late-stage lung and breast cancers. Integr Cancer Ther. 2006;5:30-9.

10. Dent AG, Sutedja TG, Zimmerman PV. Exhaled breath analysis for lung cancer. J Thorac Dis. 2013;5(Suppl 5):S540-50.

11. Bousamra M II, Schumer E, Li M, Knipp RJ, Nantz MH, van Berkel V, et al. Quantitative analysis of exhaled carbonyl compounds distinguishes benign from malignant pulmonary disease. J Thorac Cardiovasc Surg. 2014;148: 1074-80; discussion 1080-1.

12. Allard WJ, Matera J, Miller MC, Repollet M, Connelly MC, Rao C, et al. Tumor cells circulate in the peripheral blood of all major carcinomas but not in healthy subjects or patients with nonmalignant diseases. Clin Cancer Res. 2004;10:6897-904.

13. Reddy RM, Murlidhar V, Zhao L, Grabauskiene S, Zhou J, Ramnath N, et al. Pulmonary Venous Blood Sampling Significantly Increases the Yield of Circulating Tumor Cells in Early Stage Lung Cancer. J Thorac Cardiovasc Surg. 2016;151:852-8.

14. Sequist LV, Nagrath S, Toner M, Haber DA, Lynch TJ. The CTC-chip: an exciting new tool to detect circulating tumor cells in lung cancer patients. J Thorac Oncol. $2009 ; 4: 281-3$. 